\title{
Pengaruh Komitmen dan Pendapatan Terhadap Kebersamaan Pegawai Negeri Sipil Di Kota Pekanbaru
}

\author{
NOVITA \\ Sekolah Tinggi Ilmu Ekonomi Riau \\ Jln. HR. Subrantas 57 Panam Pekanbaru 28293 Telp. (0761) 63237 \\ E-mail : nofa_com@yahoo.com
}

\begin{abstract}
Mental revolution for civil servants is an important part that is inseparable and as a form of an example for the private sector and civil society in order to build cohesiveness or togetherness. Not optimal sense of suspected dipengruhi by a factor of commitment and factor income. This research method using kunatitatif and analyzed with multiple linear regression statistical analysis. Penenlitian of results proved that the commitments and revenues provide positive and significant impact on the unity government employees in providing services to the public. Problems togetherness of employees is a form of mental changes and revolutions that need to get serious attention and become the focus means. Therefore, need support in various circles.
\end{abstract}

Keywords: Commitment, Revenue and Togetherness

Kebersamaan dalam sebuah organisasi menjadi faktor yang penting, dimana pentingnya faktor ini menyangkut dari konsep kebersamaan itu sendiri yakni menjadikan kekompakan setiap kegiatan dan aktivitas dalam sebuah organsiasi. Kekompakan dalam bentuk kebersamaan ini memberikan kontribusi positif terhadap pembangunan motivasi dalam menghadapi berbagai tantangan dan cobaan yang dihadapi dalam organisasi. Saat ini dengan persaingan yang ketat antar organisasi dan juga antara sumber daya manusia membutuhkan konsep yang sangat menentukan pembangunan kebersamaan itu sendiri.

Pegawai negeri sipil merupakan bagian penting yang tak terlepaskan dan sebagai bentuk contoh bagi lembaga swasta dan lembaga kemasyarakatan dalam rangka membangun kekompakan dan atau kebersamaan. Pegawai yang memiliki rasa kekompakan yang tinggi dalam memberikan pelayanan kepada masyarakat akan menghasilkan nilai pelayanan yang berkualitas tinggi dan memuaskan keinginan masyarakat. Kondisi ini juga membawa dampak terhadap kepercayaan masyarakat kepada pegawai negeri sebagai abdi Negara.
Permasalahan saat ini yang dirasakan dan dilihat dilapangan pada lingkungan pegawai negeri sipil dalam penelitian ini dikhususnya pada pegawai negeri pada secretariat DPRD kota Pekanbaru meningindikasikan adanya kekurang kompakan atau kekurang bersamaan antara satu pegawai dengan pegawai yang lain, dengan kata lain kebersamaan di kalangan pegawai negeri sipil masih belum optimal. Kondisi ini dapat dilihat dari pelayanan yang diberikan kepada masyarakat yang cenderung lamban dan saling menunggu antar pegawai dalam bekerja dan kurang saling bersinerji dan saling mendukung dalam memberikan pelayanan.

Beberapa faktor yang diduga mempengaruhi kebersamaan ini antara lain diduga faktor komitmen dan pendapatan. Menurut Mowday dalam Sopiah (2008: 156 - 157) menyebut komitmen kerja pegawai sebagai istilah lain dari komitmen organisasional menurutnya, komitmen merupakan dimensi perilaku penting yang dapat digunakan untuk menilai kecenderungan karyawan untuk bertahan sebagai anggota organisasi. Komitmen merupakan identifikasi dan keterlibatan seseorang yang relatif kuat terhadap 
organisasi. Komitmen adalah keinginan anggota organisasi untuk tetap mempertahankan keanggotaannya dalam organisasi dan bersedia berusaha keras bagi pencapaian tujuan organisasi.

Kemudian juga Bashaw dan Grant dalam Sopiah (2008: 156) menyatakan komitmen mencakup kebanggaan anggota, kesetiaan anggota dan kemauan anggota pada organisasi. Kemudian Knoop dalam Sopiah (2008: 156) menyebutkan komitmen sebagai keberpihakan dan loyalitas karyawan terhadap organisasi dan tujuan organisasi. Robbin dalam Sopiah (2008: 156) mendefinisikan komitmen pegawai sebagai suatu sikap yang merefleksikan perasaan suka atau tidak suka dari karyawan terhadap organisasi. O'Reilly dalam Sopiah (2008: 156) menyebutkan komitmen pegawai pada organisasi sebagai ikatan kejiwaan individu terhadap organisasi yang mencakup keterlibatan kerja, kesetiaan dan perasaan percaya terhadap nilai-nilai organisasi.

Steer dan Porter dalam Sopiah (2008: 156) menyatakan bahwa suatu bentuk komitmen yang muncul bukan hanya bersifat loyalitas yang pasif, tetapi juga melibatkan hubungan yang aktif dengan organisasi kerja yang memiliki tujuan memberikan segala usaha demi keberhasilan organisasi yang bersangkutan. Timpe dalam Pangabean (2001:137) menyatakan bahwa komitmen adalah mematuhi segala sesuatu kesepakatan yang telah dibuat (kedisiplinan) tanpa dilanggar. Konsep ini diartikan bahwa komitrnen merupakan kedisiplinan seorang pegawai terhadap peraturan-peraturan di dalam organisasi yang telah disepakati bersama.

Dalam kehidupan sehari-hari komitmen sering diartikan sebagai suatu kesepakatan. Mengenai hal ini Gibson dalam Pangabean (2001:137) mengemukakan bahwa komitmen adalah rasa identifikasi dan loyalitas atau kesetiaan yang dinyatakan oleh seorang pegawai terhadap organisasi. Komitmen memberikan rasa tanggung jawab terhadap pekerjaan yang dilakukan seseorang.
Menurut Robbins (2003: 92), “Komitmen pegawai didefinisikan sebagai suatu keadaan dimana seorang pegawai memihak pada suatu organisasi tertentu dan tujuantujuannya serta berniat memelihara keanggotaan dalam organisasi itu". Komitmen pada organisasi yang tinggi dapat diartikan bahwa pemihakan pegawai (loyalitas) pada organisasi yang memperkerjakannya adalah tinggi.

Penelitian yang dilakukan oleh Debora Eflina Purba dan Ali Nina Liche Seniati Program Pascasarjana, Fakultas Psikologi, Universitas Indonesia, Depok 16424, Indonesia dalam sebuah judul Pengaruh Kepribadian Dan Komitmen Organisasi Terhadap Organizational Citizenzhip Behavior. Menghasilkan bahwa efektivitas tim kerja ditentukan oleh kemampuan anggota tim dalam berkomunikasi, bekerjasama, membagi informasi dan toleransi pada perbedaan yang terdapat di dalam tim. Semua kemampuankemampuan tersebut tercakup dalam perilaku extra-role, yang juga dikenal dengan istilah organizational citizenship behavior (OCB). Tujuan penelitian ini adalah untuk melihat anteseden OCB pada subyek karyawan di industri proses Indonesia. Dari analisis regresi berganda diketahui bahwa trait kepribadian dan komitmen organisasi berpengaruh cukup besar terhadap OCB di Indonesia.

Dari pendapat di atas, dapat disimpulkan bahwa komitmen pegawai adalah sebagai suatu keadaan dimana seorang pegawai memihak pada suatu organisasi tertentu dan tujuan-tujuannya serta berniat memelihara keanggotaan dalam organisasi itu dan memiliki hubungan yang erat dengan kebersamaan pegawai dalam sebuah organsiasi.

Selain itu juga faktor pendapatan diduga mempengaruhi kebersamaan, rasa ketidak adilan dalam mendapatkan imbalan dari hasil kerja. Istilah: "kerjo tak kerja seibu lima ratur" menjadi hal yang dianggap biasa bagi para pegawai di lingkungan 
pemerintahan. Hal ini karena mereka yang kerja dan mereka yang tidak kerja mendapatkan gaji dan hasil yang sama. Mereka yang bekerja lebih sama hasilnya dan dirasakan tidak adil bagi kalangan masyarakat dalam bekerja.

Kemudian menurut dewan penelitian pengupahan nasional dalam Husnan (2000: 138) upah ialah suatu penerimaan sebagai suatu imbalan dari pemberian kerja kepada penerima kerja untuk suatu pekerjaan atau jasa yang telah dan akan dilakukan, berfungsi sebagai jaminan kelangsungan kehidupan yang layak bagi kemanusiaan dan produksi dinyatakan atau dinilai dalam bentuk uang yang ditetapkan menurut suatu persetujuan, undang-undang dan peraturan dan dibayarkan atas dasar suatu perjanjian kerja antara pemberi kerja dan penerima kerja.

Pendapatan merupakan salah satu jenis penghargaan yang dikaitkan dengan kinerja. Menurut Long dalam Widyastuty (2007: 20) pendapatan merupakan bagian dari upah berdasarkan kinerja (performance pay) yang diberikan dalam bentuk uang dan ditetapkan berdasarkan prestasi. Semakin tinggi prestasi kerjanya, semakin besar pula Pendapatan yang diberikan.

Menurut Agency Theory dalam Widyastuty (2007: 21) pendapatan digunakan untuk mendorong karyawan dalam memperbaiki kualitas dan kuantitas hasil kerjanya. Apabila pendapatan yang diterima tidak dikaitkan dengan prestasi kerja, tetapi bersifat pribadi, maka karyawan akan merasakan adanya ketidakadilan. Dengan adanya ketidakadilan tersebut akan mengakibatkan ketidakpuasan yang pada akhirnya akan mempengaruhi perilaku.

Namun menurut para peneliti gaji berdasarkan kinerja tidak selalu cocok untuk semua jenis pekerjaan. Menurut Ruky dalam Widyastuty (2007: 23), dalam banyak pekerjaan, pengukuran prestasi kerja yang tepat tidak mungkin dilakukan dan desain serta pelaksanaannya rumit.

Konsep tentang pendapatan telah diperkenalkan oleh Frederick Taylor pada akhir tahun 1800 dalam Widyastuty (2007: 23) menyatakan bahwa yang dinamakan pendapatan adalah kompensasi yang mengaitkan gaji dengan produktivitas. Menurut Handoko (2001:176) menyatakan bahwa pendapatan merupakan penghargaan dalam bentuk finansial yang diberikan kepada mereka yang dapat bekerja melampui standar yang telah ditentukan. Istilah sistem pendapatan pada umumnya digunakan untuk menggambarkan rencana-rencana pembayaran upah yang dikaitkan baik secara langsung maupun tidak langsung dengan standar produktivitas karyawan. Karyawan yang bekerja dibawah sistem pendapatan berarti prestasi kerja mereka menentukan baik secara keseluruhan atau sebagian penghasilan mereka.

Terdapat keuntungan-keuntungan yang didapat apabila merencanakan pemberian perfomance pay yang dirancang dengan tepat menurut Long dalam Widyastuty (2007: 20) yaitu: Dapat dijadikan sebagai kunci dalam berperilaku dan peningkatan motivasi untuk mencapai prestasi. Mengurangi kebutuhan akan bentukbentuk mekanisme untuk mengontrol perilaku karyawan. Menciptakan minat dalam diri karyawan untuk berprestasi dan mencari informasi tentang tingkat prestasi terbaru. Mendukung strategi manajemen dan pencapaian tujuan organisasi.

Fungsi utama dari Pendapatan adalah untuk memberikan tanggungjawab dan dorongan kepada karyawan. Pendapatan menjamin bahwa karyawan akan mengarahkan usahanya untuk mencapai tujuan organisasi. Sistem pendapatan yang efektif mengukur usaha karyawan dan penghargaan yang didistribusikan secara adil. Menurut Widyastuty (2007: 21) usaha-usaha dapat dinilai dengan cara: Perilaku karyawan dapat dimonitor dan penghargaan berkaitan dengan perilaku tersebut. Apabila perilaku dengan mudah dapat diukur dan dimengerti, maka monitoring menjadi lebih murah dan lebih tepat. Apabila pembayaran karyawan sebagian besar berkaitan dengan perilakunya 
di tempat kerja, maka cara ini disebut Behaviour Control. Hasil kerja (output) dapat diukur dan tingkat output itu menentukan penghargaan. Cara pengukuran berdasarkan hasil kerja disebut output control.

Jenis jenis pendapatan meliputi : 1). Pendapatan individu. Pendapatan individu bertujuan untuk memberikan penghasilan tambahan selain gaji pokok bagi individu yang dapat mencapai standar prestasi tertentu. Insentif individu dapat diberikan berdasarkan kuantitas hasil kerja atau berdasarkan waktu (timing). 2). Pendapatan kelompok. Pendapatan kelompok merupakan pendapatan yang diberikan karena menghasilkan sebuah produk yang membutuhkan kerjasama dengan orang lain. Terdapat tiga cara pembayaran Pendapatan kelompok yaitu : Seluruh anggota menerima pembayaran yang sama dengan pembayaran yang diterima oleh mereka yang paling tinggi prestasinya. Seluruh anggota menerima pembayaran yang sama dengan pembayaran yang diterima oleh mereka yang paling rendah prestasinya. Seluruh anggota menerima pembayaran yang sama dengan rata rata pembayaran yang diterima oleh kelompok.

Menurut Locke dalam dalam Widyastuty (2007: 22) menyatakan bahwa pendapatan berupa uang lebih dapat meningkatkan produktivitas dibandingkan dengan teknik-teknik lainnya, seperti penetapan tujuan, partisipasi karyawan dalam pengambilan keputusan dan pemerkayaan pekerjaan (job enrichment). Adapun syaratsyarat yang patut dipenuhi dalam pemberian pendapatan agar tujuan pemberian pendapatan dapat diwujudkan sebagai berikut : Sederhana, peraturan dari sistem pendapatan haruslah singkat, jelas dan dapat dimengerti. Spesifik, karyawan perlu tahu dengan tepat apa yang diharapkan untuk mereka yang lakukan. Dapat dicapai, setiap karyawan seharusnya mempunyai kesempatan yang masuk akal untuk memperoleh sesuatu. Dapat diukur, sasaran yang dapat diukur merupakan dasar untuk menentukan rencana pendapatan.
Sebuah pendapatan harus dirancang sedemikian rupa sehingga memenuhi kebutuhan dan situasi tertentu yang spesifik. Sistem pemberian pendapatan pada masingmasing organisasi berbeda, dimana sistem pendapatan dapat berjalan dengan baik pada satu organisasi, mungkin akan gagal diterapkan pada organisasi yang lain. Program pendapatan yang terbaikpun tetap akan mempunyai beberapa hambatan pada waktu diterapkan pertama kali dan membutuhkan beberapa penyesuaian sebelum akhirnya menghasilkan apa yang diharapkan.

Program pendapatan yang baik memang cenderung meningkatkan prestasi individu dan produktivitas. Tetapi beberapa program, terutama program yang menekankan prestasi individu, justru menghambat peningkatan output karena terjadi "kolusi" antara sesama pekerja. Alasan mereka membuat begitu adalah adanya kecurigaan di antara para pekerja/karyawan bahwa output yang tidak dibatasi atau dihambat justru akan menyebabkan organisasi menurunkan besarnya pendapatan atau memperkecil kesempatan untuk berpindah penugasan. Agar program pendapatan yang kita rancang efektif, kita harus berusaha keras menghilangkan kecurigaan pekerja tersebut.

Kemudian apabila berbicara mengenai pendapatan, maka tidak bisa dilepaskan dengan pembicaraan kompensasi atau upah sebab pendapatan merupakan bagian dari sistem kompensasi. Terdapat banyak pendapat yang menyampaikan tentang kompensasi antara lain: Moekijat (2001: 161) menjelaskan kompensasi adalah apa yang diterima pegawai sebagai pertukaran pekerjaannya. Apakah itu upah jam-jaman atau gaji berkala, bagian personalia biasanya merencanakan dan mengelola kompensasi pegawai. Apabila kompensasi itu dilaksanakan dengan cermat, maka pegawai kemungkinan besar akan merasa puas dan dimotivasi untuk mencapai tujuannya dari tenaga kerja yang efektif. 
Akan tetapi apabila pegawai menerima kompensasi yang tidak memadai, maka pelaksanaan pekerjaan, motivasi, dan kepuasan mungkin akan berkurang.

Program kompensasi memelihara sumber daya manusia dari suatu organisasi. Apabila upah dan gaji tidak dikelola dengan baik, maka perusahaan mungkin akan kehilangan pegawai-pegawai dan biaya yang dikeluarkan untuk menarik, memilih dan mengembangkan mereka. Meskipun pegawaipegawai tidak berhenti dari pekerjaan, mereka mungkin merasa tidak puas terhadap perusahaan. Jumlah pembayaran total atau mutlak terlalu rendah, maka pegawai tidak dapat memenuhi fisiologis atau kebutuhan keamanannya. Dalam masyarakat industri, tingkat pembayaran absolut biasanya cukup tinggi untuk memenuhi kebutuhan dasarnya, sekurang-kurangnya minimal. Suatu sumber ketidakpuasan yang tidak umum memusatkan pada pembayaran relatif, yakni pembayaran pegawai dibandingkan dengan pembayaran dari pegawai lain.

Tingkat pembayaran yang mutlak dan yang relatif juga dapat mengandung akibatakibat yang negatif bagi organisasi. Dalam kejadian-kejadian tertentu, keinginan akan pembayaran yang lebih banyak dapat melibatkan pegawai-pegawai mencari jabatan atau pekerjaan baru. Daya tarik yang lebih rendah dari jabatan-jabatan mereka dapat menimbulkan ketidakpuasan jabatan, ketidakhadiran atau akibat-akibat lain yang tidak diinginkan. Bahkan pembayaran upah atau gaji yang lebih banyak dari semestinya dapat merugikan organisasi dan orangorangnya. Biaya kompensasi yang tinggi dapat mengurangi kedudukan bersaing majikan dan kemampuan mendatang untuk memenuhi kebutuhan pembayaran. Bagi pegawai-pegawai yang dibayar lebih dari semestinya, mereka mungkin merasa gelisah, salah dan tidak senang.

Selanjutnya oleh Moekijat (2001: 137) kompensasi dibedakan dengan gaji atau upah. Kompensasi adalah imbalan jasa yang diberikan kepada pegawai, karena yang bersangkutan telah memberikan sumbangan untuk mencapai tujuan organisasi. Dalam istilah kompensasi termasuk gaji, upah, perumahan pegawai, pakaian, tunjangan pangan dan tunjangan-tunjangan lainnya. Menurut Husnan (2000: 138) upah adalah tiap-tiap pembayaran berupa uang yang diterima pekerja sebagai ganti pekerjaan. Kemudian juga berupa perumahan, makanan, bahan makanan dan pakaian secara percuma, bonus dan lain sebagainya.

Upah dalam arti yang sempit dipergunakan untuk menunjukkan pembayaran yang diberikan kepada pegawai jam-jaman atau pegawai yang bukan pegawai tata usaha dan pegawai-pegawai lainnya yang pekerjaanya tidak melakukan pengawasan. Upah yang sesungguhnya atau sering disebut upah saja adalah dasar upah kali jam kerja (upah berdasarkan waktu) atau dasar upah kali satuan yang dihasilkan (upah satuan atau upah borongan atau upah pendapatan). Upah riil menunjukkan daya beli pembayaran berupa uang, premi, tetapi tidak termasuk potongan untuk kesejahteraan sosial, pajak penghasilan, surat obligasi, asuransi dan beban-beban lainnya. Dengan kata lain, upah bersih adalah pendapatan dikurangi potongan pajak, kesejahteraan sosial, asuransi iuran sarikat kerja, sumbangan-sumbangan dan lain-lainnya.

Menurut Teguh (2003: 208) tujuan kompensasi adalah: Untuk memperoleh pegawai yang cakap. Upah dan gaji harus cukup tinggi untuk menarik para pelamar. Tingkat pembayaran harus sesuai dengan permintaan dan penawaran. Untuk mempertahankan pegawai-pegawai lama. Apabila tingkat upah atau gaji rendah, maka beberapa pegawai akan berhenti dari pekerjaan. Untuk mencegah perpindahan pegawai maka tingkat pembayaran harus memadai. Untuk menjamin keadilan. Administrasi upah dan gaji berusaha mendapatkan keadilan internal dan eksternal. Keadilan internal adalah pekerjaan pekerjaan sama harus mendapat pembayaran yang sama pula. Keadilan eksternal adalah pembayaran 
pegawai pada suatu tingkat yang sama dengan pembayaran kepada pegawai pada suatu tingkat yang sama dengan pembayaran yang diperoleh pegawai tersebut dalam organisasi lain.

Adapun fungsi kompensasi yang menunjang efektivitas organisasi adalah: Kompensasi dapat dipergunakan untuk menarik pelamar-pelamar yang cakap bagi organisasi; Kompensasi membantu memperoleh pegawai-pegawai yang cakap dalam organisasi; Kompensasi dapat dipergunakan sebagai perangsang untuk memotivasi para pegawai memberikan usahausaha mereka yang terbaik; Mengurangi sebanyak-banyak biaya organisasi dapat juga menunjang keefektifan organisasi, karena kompensasi merupakan biaya yang penting bagi kebanyakan organisasi (Moekijat, 2001: 145-146)

Berkaitan dengan sistem pendapatan Taylor akhir 80 an menaruh perhatian dengan apa yang disebutnya sistematik soldering (penyerdaduan sistematis). Kondisi ini dilihatnya: Kecenderungan pegawai untuk bekerja selambat mungkin; menghasilkan pada level minimum yang dapat diterima; bahwa karyawan masih memiliki energi untuk bekerja 12 jam diperusahaan (energi residu); Apabila ia dapat menemukan cara memanfaatkan energi residu itu dalam bekerja, maka akan dapat dicapai tingkat produktivitas yang tinggi; Pada waktu itu yang digunakan adalah sistem kerja borongan tradisional. Dimana pegawai yang melebihi quota tiap potong yang dihasilkan, dikenakan pemotongan upah.

Kebersamaan yang menjadi faktor penting dalam membangun kinerja organisasi diduga dipengaruhi oleh komitmen dan pendapatan. Penelitian ini bermaksud membuktikannya pada pegawai pemerintah.

\section{METODE}

Penelitian ini menggunakan pendekatan survey, yang dilakukan kepada seluruh pegawai di lingkungan secretariat DPRD kota Pekanbaru dengan responden berjumlah 56 orang dan dianalisis dengan menggunakan regresi linier berganda dan dikombinasikan dengan gambar SEM.

\section{HASIL}

Berdasarkan hasil survey yang dilakukan di lapangan berkaitan dengan membuktikan pengaruh variabel komitmen dan pendapatan terhadap kebersamaan, maka dapat diperoleh beberapa informasi sebagai berikut:

1. Komitmen memberikan pengaruh positif dan sinifikan terhadap kebersamaan

2. Pendapatan memberikan pengaruh positif dan signifikan terhadapa kebersamaan

3. Pendapatan memberikan kontribusi kebih besar bila dibandingkan dengan komitmen dalam membangun kebersamaan.

4. Berikut ini hasil pengolahannya:

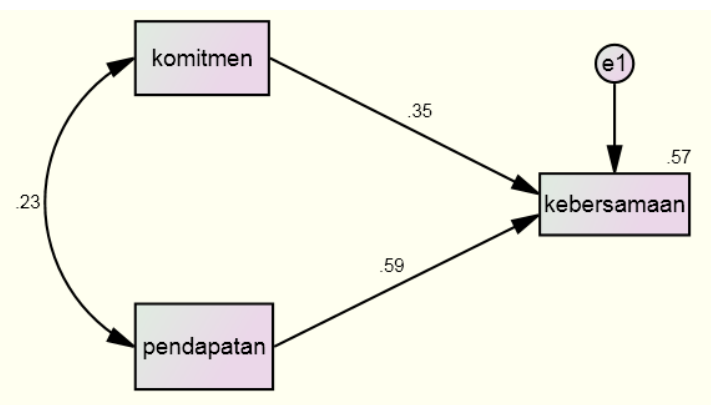

Pengaruh komitmen positif dan signifikan terhadap kebersamaan yang mengandung arti bahwa semakin tinggi komimen semakin tinggi juga kebersamaan, besarnya pengaruh komitmen yakni 0,346 yang bermakna apabila komitmen meningkat satu satuan, maka kebersamaan akan meningkat sebesar 0,346 satuan. Peningkatan ini juga berpengaruh signifikan terhadap kebersamaan.

Kemudian pengaruh pendapatan terhadap kebersamaan sebesar 0,594 yang bermakna bahwa apabila keadilan dalam memberikan pengasilan kepada pegawai dinilai baik, maka kebersamaan antara pegawai dalam mencapai tujuan organisasi 
juga akan meningkat. Peningkatan ini sebesar 0,594 artinya bahwa apabila terjadi peningkatan keadilan dalam pemberian penghasilan kepada pegawai sebesar satu satuan maka akan meningkatkan kebersamaan sebesar 0,594.

Kedua variabel tersebut memberikan kontribusi terhadap kebersamaan sebesar 0,57 satuan atau $57 \%$ rasa kebersamaan antar pegawai dalam bekerja itu dipengaruhi oleh komitmen pegawai dalam bekerja dan pendapatan yang diberikan kepada pegawai dalam bentuk keadilan penghasilan. Sedangkan sisanya sebesar $43 \%$ dipengaruhi oleh faktor lain yang tidak diteliti dalam penelitian ini.

\section{PEMBAHASAN}

Pembangunan rasa kebersamaan kepada pegawai pemerintah menjadi barometer dalam pembangunan mental manusia, revolusi mental yang pada saat ini menjadi focus pemerintahan Jokowi memberikan manfaat bagi tenaga kerja dalam hal ini adalah pegawai dan dimulai dari mental pegawai dalam bekerja, memberikan pelayanan dengan mental yang benar-benar menjadi abdi Negara dan abdi rakyat. Karena pemerintah menjadi teladan bagi rakyatnya, sector dunia usaha dan sector organisasi kemasyarakatan mencari teladan dari pemerintah. Pemerintah yang tegas dalam menegakkan kondisi ini akan memberikan nilai lebih (value added) bagi mental dan perkembangan perilaku pegawai dalam bekerja.

Penelitian ini berhasil membuktikan bahwa rasa kebersamaan yang merupakan mental pegawai dalam memberikan pelayanan kepada masyarakat dipengaruhi oleh rasa komitmen pegawai tersebut dalam memberikan pelayanan kepada masyarakat. Pegawai menyadari dengan seksama bahwa mereka adalah pelayanan rakyat dan perlu kompak dalam menghadapi berbagai persoalan yang ada.

Selain itu juga dapat diketahui bahwa pendapatan dan maksudnya adalah memberikan gaji yang adil kepada pegawai menjadi perhatian khusus dalam meningkatkan rasa kebersamaan. Rasa kebersamaan akan terbangun dengan adanya pemberian gaji yang adil dan mereka yang bekerja lebih akan mendapatkan gaji yang lebih dan sebaliknya mereka yang bekerja sedikit akan mendapatkan gaji yang sedikit. Hasil penelitian ini mendukung penelitian terdahulu seperti yang disampaikan oleh Debora (2014) tentang komitmen dan Widyastuty (2007) tentang pendapatan.

\section{SIMPULAN}

Perubahan pegawai dan dimulai dari mental pegawai dalam bekerja, memberikan pelayanan dengan mental yang benar-benar menjadi abdi Negara dan abdi rakyat. Karena pemerintah menjadi teladan bagi rakyatnya, sector dunia usaha dan sector organisasi kemasyarakatan mencari teladan dari pemerintah. Pemerintah yang tegas dalam menegakkan kondisi ini akan memberikan nilai lebih (value added) bagi mental dan perkembangan perilaku pegawai dalam bekerja.

Terbukti bahwa komitmen dan pendapatan memberikan pengaruh positif dan signifikan terhadap kebersamaan pegawai pemerintah dalam memberikan pelayanan kepada masyarakat. Permasalahan kebersamaan dari pegawai merupakan bentuk perubahan dan revolusi mental yang perlu terus mendapatkan perhatian yang serius dan menjadi focus yang berarti. Oleh karenanya perlu dukungan diberbagai kalangan.

\section{DAFTAR RUJUKAN}

Debora Eflina Purba dan Ali Nina Liche Seniati Program Pascasarjana, Fakultas Psikologi, Universitas Indonesia, Depok 16424, Indonesia dalam sebuah judul Pengaruh Kepribadian Dan Komitmen Organisasi Terhadap Organizational Citizenzhip Behavior. 
Handoko, T. Hani, 2001, Manajemen, BPFE, Siagian, Sondang, 2008, Manajemen Sumber Yogyakarta. Daya Manusia, Bumi Aksara,

Husnan, Heidjrachman, Suad, 2000, Jakarta.

Manajemen Personalia Edisi 4., Sopiah, 2008, Perilaku Organisasional, BPFE Yogyakarta, Yogyakarta. Andi, Yogyakarta.

Moekijat, 2001, Manajemen Personalia dan Sumber Daya Manusia, Mandar Maju, Bandung.

Pangabean, Mutiara, Sibarani, 2001, Manajemen Sumber Daya Manusia, Ghalia Indonesia, Bogor.

Robbins, Sthepen, 2003, Perilaku Organisasi, Terjemahan Tim Indeks. Indeks Garamedia, Jakarta.

Robins, 2001, Teori Organisasi, Arcan, Jakarta.

Teguh, Ambar Teguh Sulistiyani, 2003, Manajemen Sumber Daya Mausia, Konsep, Teori dan Pengembangan dalam Konteks Organisasi Publik, Graha Ilmu, Yogyakarta.

Widyastuty, 2007, Pengaruh Insentif terhadap Prestasi Kerja Pegawai, Tesis, UNAIR. 